\title{
Cemeteries: The Neglected Public Spaces
}

\author{
Saumya Gupta* and Vaibhav Agarwal \\ School of Planning and Architecture, Bhopal, India
}

\begin{abstract}
A space for the incineration of the departed taking into consideration the sacred rituals are called a cremation ground. It behaves as a bystander but it can also stimulate one of the strongest emotions felt by a human namely, grief. This grief, if not taken care of, can render a person mentally emotionless and physically unavailable. A crematorium, built for the primary purpose of letting go of the deceased, should also cater to the grief and sadness of the ones left behind. This place should help them release their emotions, accept the reality and finally reintegrate them with their natural environment. This space should not hinder the process of the ritual but should also help the person, spiritually, in the sound fulfillment of it. This practice seems a little lost in the cremation grounds of the modern times where practicality is valued over the psychological impact of the space. This paper discusses ways to stimulate the senses of a mourning human and help them overcome their emotions and confusion through intervention of landscape elements. To fulfill this, a qualitative research has been done, which analyzes the situation of existing crematoriums leading to the formation of certain guidelines discussing the architecture of death.
\end{abstract}

Keywords: Grief, Crematorium, Landscape, Psychology, Quality of Life, Infrastructure, Ritual, Traditional Practice, Human Behavior

\section{Introduction}

'Antyesti', the final stage of life, the funeral, is divided into 5 sequential parts, namely, preparation of the dead, cremation, mourning, purification of the bereaved and commemoration.

Since time immemorial, the places for the dead have been designed exactly like that, dead. These spaces are supposed to have a second function as well, which is equally as important as the liberation of the dead. This is the mourning or the healing of those left behind or the bereaved.

A cremation ground must focus on all the five aspects of the final stage of life, and thus the need for new and modern ideals for designing a cremation space arises. The taboos and stigmas regarding death culture need to be given a back seat and sensitivity must be ushered in. 




Figure 1: The spaces in a cemetery are not of any real use until some kind of treatment is done to make them interactive and helpful for the users. (Source: Author)

\section{Aims and Objectives}

- To find out the certain landscape elements which can help shape and create a more inclusive cemetery.

- To gather insight on the workings of a human mind through interviews with people representing the suffering, the aiding and the working.

- To relate psychology and religiosity, and integrate them together in the form of landscape elements which can be used in the designing of a cremation ground.

- To try and create a holistic public space, catering to people belonging to all kinds of sects.

- To try and break from the taboos of death.

- To generate healing and positivity out of negative space through landscape and architecture. 




Figure 2: Methodology Chart (Source: Author)

\section{Research Questions}

- What are the factors affecting the psychology of humans at a cremation ground considering different scenarios?

- Are boundaries necessary for a cremation ground?

- What can be the alternative functions which can be integrated within the cremation ground to help destigmatize people and normalize death culture around the world?

- How can landscape elements help in shaping a negatively perceived place into a positive one?

- Can cemeteries cater to the needs of both the dead and living?

\section{Methodology}

To understand the psychology of the people and to gain understanding of the various landscaping techniques and principles used around the world, literature study has been done regarding Feng shui and the role of our five senses in our lives.

For the better understanding of the functioning of a cemetery and the spaces required, various case studies have been taken up and discussed.

And the last approach to understand the people in and around the cemetery, public opinions were taken, keeping into consideration the bereaved, the mourning and the workers of the cemetery. 


\section{Literature Review}

\section{Concepts in Landscaping}

\section{Feng Shui:}

Feng Shui literally translates to wind and water. This is a traditional Chinese concept of integrating the man with his environment, to ensure harmony and peace within and outside.

The basic five elements in nature- wood, fire, earth, metal and water are used to create a harmonious and balanced environment.

\section{Five Senses:}

Our natural world is built around the five senses of touch, sound, sight, smell and taste. Any structure built keeping these senses alive leads to the physical as well as mental wellbeing of the people using that structure as well as the environment.

\section{Philosophy of Zen:}

The principles of Zen govern all aspects of life and hence, naturally design as well. The Zen culture of Japan represents the concept of 'Shibumi' which means simple, subtle and unobtrusive beauty. This concept glorifies the idea that a great design is obvious and hence should be achieved.

\section{Case Studies (Part 1)}

- $\quad$ Shadow Spaces (Green Park, New Delhi, India)

This cemetery in Delhi, built by the architect Sanchit Arora, tries to bring back the lost virtues, values and sanctity in cemeteries which has arisen due to the decline ritualistic practices.

The Shadow Spaces cemetery hosts a remembrance hall for the mourners, which helps to cater to the healing process of the mourners. The whole compound of the cemetery is packed with different instances of water bodies, as just the mere sound is enough to provide harmony and peace. In addition to this, water also plays an important part in the crematorial rites.

The light and shadow play brought by the roof of the path leading to the main funeral grounds, helps in distracting the mind of the mourners.

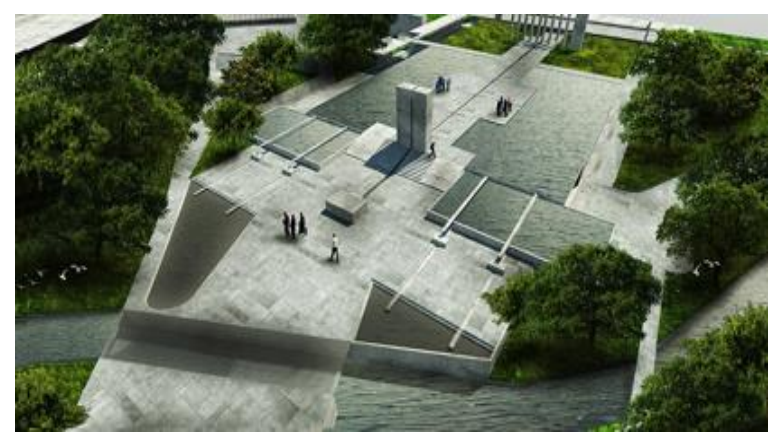

Figure 3: Gathering Space. (Source: DesignBoom) 


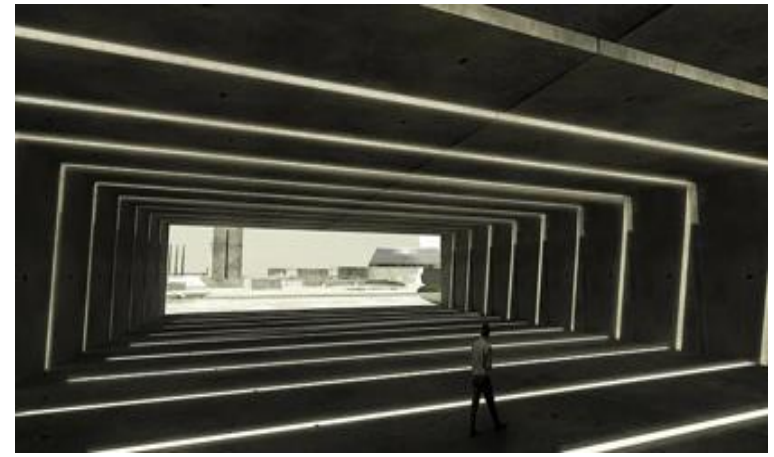

Figure 4: Path to main Funeral Grounds. (Source: DesignBoom)

- Church of Light (Ibaraki, Osaka, Japan)

The Church of Light is one of Tadao Ando's signature architectural works. It is made bereft of any physical idols, instead it makes the church light up with the help of a huge cross in one of the walls of the church. This light becomes the holy entity of the church.

This intervention implies that natural elements can be used instead of direct instances of elements for a similar purpose. The use of natural elements helps in bridging the gap between people and their environment. This also aids in opening people up to their senses.

The diagonal wall used at the entrance guides most of the movement inside the church, along the single source of light, the cross.

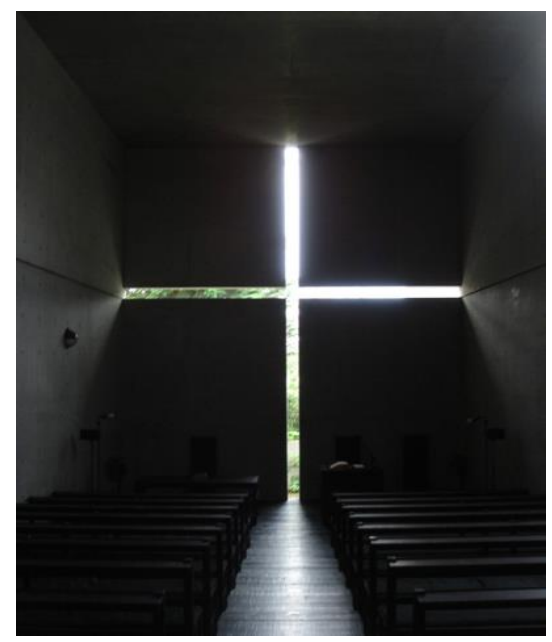

Figure 5: The Cross. (Source: ArchDaily) 


\section{Case Studies (Part 2)}

- Shamshan Ghat (Bairagarh, Bhopal, India)

This cemetery takes up 4.2 acres of area.

A circular path runs all around the cemetery, connecting the various spaces.

The multiple piers for cremating are constructed under a common roof, raised on a common plinth.

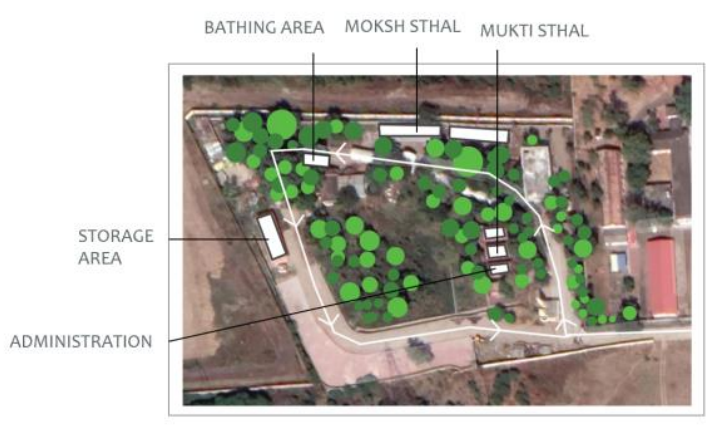

Figure 6: Site map of Shamshan Ghat at Bairagarh, Bhopal, India (Map Source: Google Earth)

- Shamshan Ghat (Bhadbhada Road, Bhopal, India)

The cemetery takes up 4.9 acres of area.

A straight, cemented path connects all the various spaces.

Multiple piers are constructed under a common roof and raised on a common plinth.

The path has wild vegetation growing on both sides majorly, before and after the funeral pyre area.

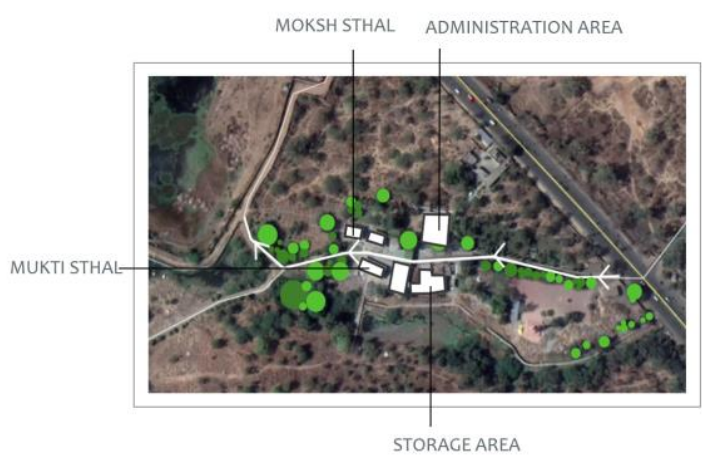

Figure 7: Site map of Shamshan ghat at Bhadbhada Road, Bhopal, India (Map Source: Google Earth)

- Vaikuntha Mahaprasthanam Crematorium (Hyderabad, India)

This cemetery takes up an area of 3.7 acres.

It has been designed, based on Hindu rites and rituals, both contextually and culturally.

Two types of structures, pavilions and pyres, are designed. The first, are enclosed to comfort and console loved ones, the latter which open skywards to liberate the lost in a final farewell.

The open structures all have tilted walls opening up towards the sky, signifying the liberation of the dead. 


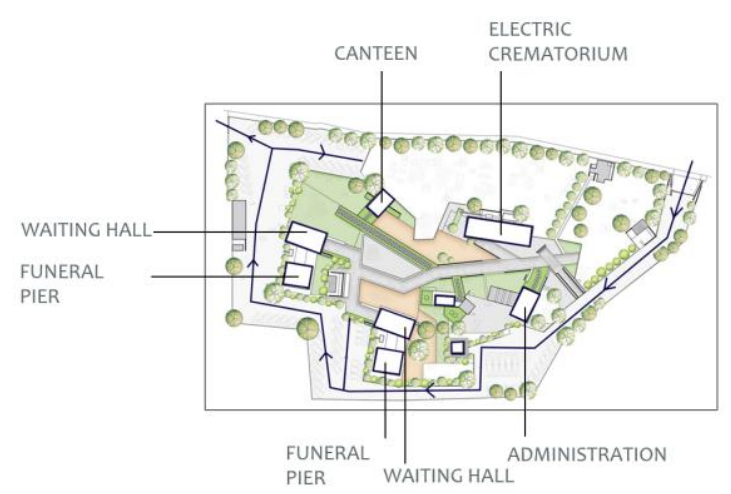

Figure 8: Site map of Vaikuntha Mahaprasthanam Cemetery, Hyderabad, India (Map Source: ArchiExpo)

\section{Spaces in a Cemetery}

\section{The Usual:}

The Path: The main circulation space connecting all the various spaces in a cemetery.

Administration

Mukti Sthal: The space where the pre-funerary rites are carried out.

Moksh Sthal: The space where the body is cremated. These can be of two types, electric crematoriums and traditional funeral piers.

Changing rooms/ Showers/ Toilets

Waiting rooms

Storage area

Parking

Additional:

Gathering Spaces: For the friends and family of the deceased to sit and mourn.

Remembrance Halls: for the bereaved to create something in the memory of the deceased.

Self-Reflective Spaces: for the bereaved to spend some time in peace so as to come to terms with the reality.

Landscaping: Inspired by the concepts of five senses and Feng Shui to create a harmonized and balanced environment. 


\section{Comparative Analysis}

Table 1: Comparative Analysis of the various Shamshan Ghats discussed in Case Study Part 2. (Source: Author)

\begin{tabular}{|c|c|c|c|}
\hline & $\begin{array}{l}\text { Shamshan Ghat, } \\
\text { Bairagarh }\end{array}$ & $\begin{array}{l}\text { Shamshan } \\
\text { Ghat,Bhadbhada Road }\end{array}$ & $\begin{array}{l}\text { Vaikunta Mahaprasthanam, } \\
\text { Hyderabad }\end{array}$ \\
\hline Circulation & $\begin{array}{l}\text { Cemented circular path } \\
\text { with separate ways for } \\
\text { both entry and exit. }\end{array}$ & $\begin{array}{l}\text { One way Path with } \\
\text { cemented flooring. }\end{array}$ & $\begin{array}{l}\text { One way path, separate } \\
\text { pedestrian and vehicular } \\
\text { movement. }\end{array}$ \\
\hline Main Ritual Area & 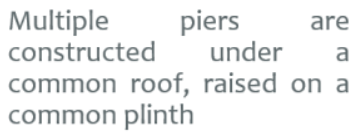 &  & $\begin{array}{l}\text { Each funeral pier is given its } \\
\text { own walls and a clear view to } \\
\text { the water body on site. }\end{array}$ \\
\hline Landscaping/ Vegetation & $\begin{array}{l}\text { Vegetation is left to grow } \\
\text { on its own. } \\
\text { No intentional landscaping } \\
\text { is done. } \\
\text { This wild vegetative area is } \\
\text { also used the area for small } \\
\text { graves. }\end{array}$ & $\begin{array}{l}\text { The path has wild } \\
\text { vegetation growing on } \\
\text { both sides majorly, before } \\
\text { and after the funeral pyre } \\
\text { area. }\end{array}$ & $\begin{array}{l}\text { Landscaping has been given a } \\
\text { priority and has been done to } \\
\text { create harmonious spaces for } \\
\text { the bereaved and the } \\
\text { mourning to spend time and } \\
\text { reflect. }\end{array}$ \\
\hline Special Features & & & $\begin{array}{l}\text { Tilted walls for the main ritual } \\
\text { area make for privacy and } \\
\text { intimacy during the ritual } \\
\text { process. }\end{array}$ \\
\hline
\end{tabular}

\section{People's Perspectives}

The Bereaved:

- At the time of the rituals, the bereaved is simply following what they are being told. The only thing going through their mind is the uninterrupted completion of all the rites.

- The first step of the healing of the bereaved should start from the cemetery itself. A cemetery should provide for the healing through the use of landscaping elements which affect the person subconsciously.

- The death of a loved one stirs up a multitude of emotions. Research shows that people can cope with such losses over time with the help from their environment and society.

The Mourning:

- The many people accompanying the bereaved, with a not so close connection to the deceased, should also be catered to and not neglected.

- These people are more conscious than the bereaved and can grasp and make sense of their surroundings.

- These people need the landscape and their surroundings to be soothing in both the functional and the aesthetic aspects.

- The mourners are there to support the bereaved, and thus the design of the cemetery should also support them. 


\section{The Workers:}

- The workers in a cemetery get exposed to death on a daily basis, so much so that death becomes normal to them. On their own they tend to normalize the death culture.

- For them, the cemetery acts as a barrier from the outer world. They are respected inside the cemetery but are not fully accepted in the outer world.

- "Log aate hain, hum unka kriya karam karwa dete hain. Bas yahi hai.” (People come here; we help them with the rituals. That's it.) These lines were said by Neeta Aunty, a worker in the Bairagarh Shamshan Ghat in Bhopal.

\section{Comparative Analysis}
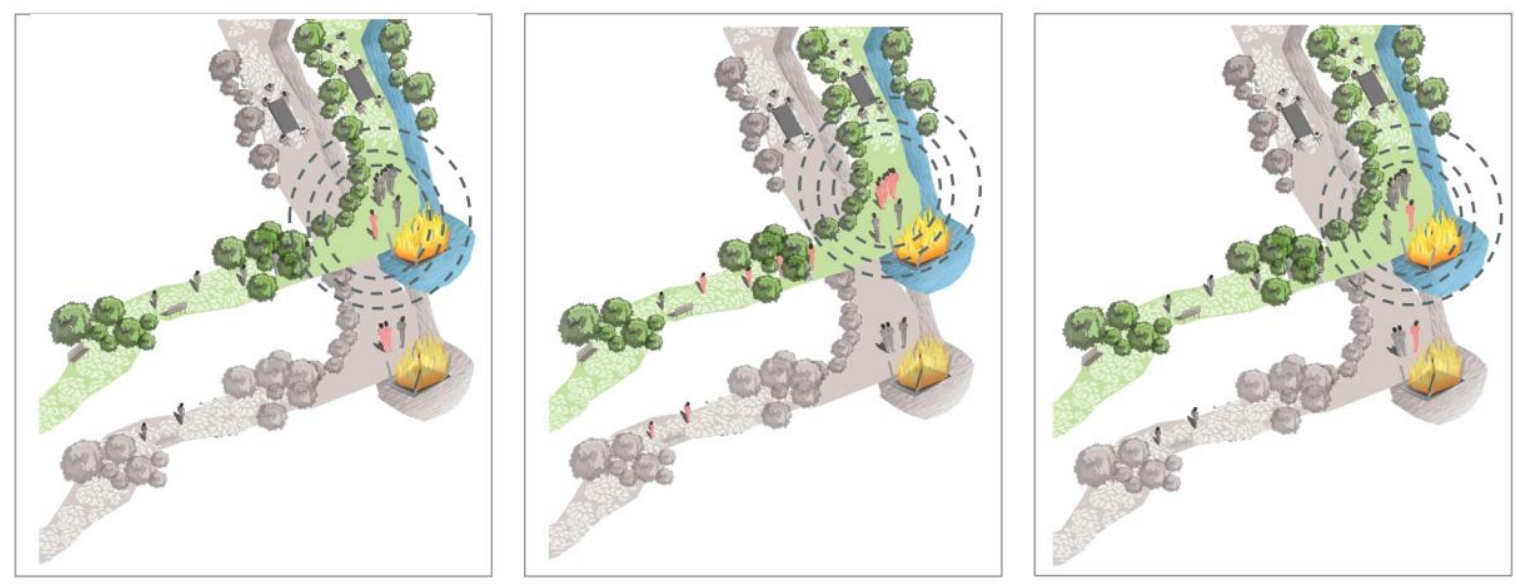

Figure 9: The path of the cemetery showing the roles of the bereaved, the mourning and the workers during the performing of rites. (Source: Author)

\section{Conclusion}

The study helps in finding the ways in which a cemetery can be made more approachable and accepted by the common people. The integration of various concepts like Zen, Feng Shui and Five Senses can make even a place cemetery, more austere and holy.

Addition of areas like Gathering spaces, Remembrance halls, Self- Reflective spaces and above all, appropriate landscaping can make it easier for the bereaved to mourn their loss and get accustomed to the grief. A little more attention to the design and a bit more sensitivity for the users makes all the difference.

Table 2: Comparative Analysis of the different categories of people present in a cemetery during the performing of rites. (Source: Author) 


\begin{tabular}{|c|c|c|c|c|}
\hline & About & Why visit a Cemetery? & How long is the visit? & How can the cemetery cater? \\
\hline The Bereaved & $\begin{array}{l}\text { The immediate kin of } \\
\text { the deceased. }\end{array}$ & $\begin{array}{l}\text { To perform the last rites } \\
\text { and rituals for the earthly } \\
\text { departure of deceased. }\end{array}$ & 3-4 hours & $\begin{array}{l}\text { Places of self- reflection } \\
\text { which help in coming to } \\
\text { terms with the reality. } \\
\text { Landscaping which heals } \\
\text { subconsciously. }\end{array}$ \\
\hline The Mourning & $\begin{array}{l}\text { The acquaintances } \\
\text { and friends of the } \\
\text { deceased. }\end{array}$ & $\begin{array}{l}\text { To support the bereaved } \\
\text { in performing the rites } \\
\text { and mourn for the } \\
\text { deceased. }\end{array}$ & 2-3 hours & $\begin{array}{l}\text { Places of gathering to mourn } \\
\text { for the deceased. } \\
\text { Better aesthetics to make } \\
\text { the people feel better. } \\
\text { Aesthetics along with } \\
\text { functionality in landscaping } \\
\text { to soothe both the eyes and } \\
\text { the soul. }\end{array}$ \\
\hline The Workers & $\begin{array}{l}\text { The people working } \\
\text { in a cemetery, who } \\
\text { also help with the } \\
\text { rites. }\end{array}$ & $\begin{array}{l}\text { To support their own } \\
\text { livelihood and help the } \\
\text { people perform the rites } \\
\text { correctly. }\end{array}$ & 24 hours, everyday & $\begin{array}{l}\text { Different functions can be } \\
\text { provided in a cemetery to } \\
\text { normalise the death culture } \\
\text { and to provide a way of } \\
\text { interaction to the outside } \\
\text { world for the workers. }\end{array}$ \\
\hline
\end{tabular}

The following points can also be considered:

1. The path leading to the Moksh Sthal can be designed in a way that it devoid of any physical disturbances and helps the bereaved perform the rituals in a mild manner. Whereas the path from the Moksh Sthal to the exit of the cemetery can be designed such that it provides spaces for self-introspection and passive interaction.

2. The materiality also plays a big part in how the place ends up being perceived. The materials to build the cemetery can be more nature friendly so that the cemetery fells one with the nature and the whole process feels natural to the bereaved.

The addition of such passively interactive spaces and design interventions can not only help gradually disperse the grief but also will allow for the cemeteries to break the general stereotype of taboo spaces and start their journey to becoming spaces of release and remembrance.

\section{References}

Crockett, L. (2016, August 20). Sacred Landscapes or "Taboo Spaces" in Indian Crematoriums. Retrieved from ArchDaily: https://www.archdaily.com/793545/arora-sanchit-speculates-on-the-role-of-crematoriums-in-india

D A Studios, N. B. (2015, December 29). DA studios updates mahaprasthanam hindu crematorium \& cemetery in india. Retrieved from DesignBoom: https://www.designboom.com/architecture/da-studios-mahaprasthanamhindu-crematorium-cemetery-india-12-29-2015/

Kroll, A. (2011, January 6). AD Classics: Church of the Light / Tadao Ando Architect \&amp; Associates. Retrieved from ArchDaily: https://www.archdaily.com/101260/ad-classics-church-of-the-light-tadao-ando

Sanchit Arora, N. B. (2016, July 6). sanchit arora's speculative shadow spaces crematorium in india conceived as a sacred landscape. Retrieved from DesignBoom: https://www.designboom.com/architecture/sanchit-arorashadow-spaces-crematorium-concept-07-06-2016/

Vaikunta Mahaprasthanam. (n.d.). Retrieved from Vaikunta Mahaprasthanam: http://www.vaikuntamahaprasthanam.com/index.html 